\title{
The Rewarding and Locomotor-Sensitizing Effects of Repeated Cocaine Administration are Distinct and Separable in Mice
}

\author{
Thorfinn T. Riday, B.A. ${ }^{1}$, Barry E. Kosofsky, M.D., Ph.D. ${ }^{2}$, and C.J. Malanga, M.D., Ph.D. ${ }^{1}$ \\ ${ }^{1}$ Laboratory of Developmental Neuropharmacology; Department of Neurology; University of North \\ Carolina at Chapel Hill \\ ${ }^{2}$ Department of Pediatrics; Weill Medical College of Cornell University
}

\begin{abstract}
Repeated psychostimulant exposure progressively increases their potency to stimulate motor activity in rodents. This behavioral or locomotor sensitization is considered a model for some aspects of drug addiction in humans, particularly drug craving during abstinence. However, the role of increased motor behavior in drug reward remains incompletely understood. Intracranial self-stimulation (ICSS) was measured concurrently with locomotor activity to determine if acute intermittent cocaine administration had distinguishable effects on motor behavior and perception of brain stimulation-reward (BSR) in the same mice. Sensitization is associated with changes in neuronal activity and glutamatergic neurotransmission in brain reward circuitry. Expression of AMPA receptor subunits (GluR1 and GluR2) and CRE binding protein (CREB) was measured in the ventral tegmental area (VTA), dorsolateral striatum (STR) and nucleus accumbens (NAc) before and after a sensitizing regimen of cocaine, with and without ICSS. Repeated cocaine administration sensitized mice to its locomotor stimulating effects but not its ability to potentiate BSR. ICSS increased GluR1 in the VTA but not NAc or STR, demonstrating selective changes in protein expression with electrical stimulation of discrete brain structures. Repeated cocaine reduced GluR1, GluR2 and CREB expression in the NAc, and reductions of GluR1 and GluR2 but not CREB were further enhanced by ICSS. These data suggest that the effects of repeated cocaine exposure on reward and motor processes are dissociable in mice, and that reduction of excitatory neurotransmission in the NAc may predict altered motor function independently from changes in reward perception.
\end{abstract}

\section{Keywords}

Intracranial Self-Stimulation; Brain Stimulation Reward; Sensitization; GluR1; GluR2; CREB

\section{(C) 2011 Elsevier Ltd. All rights reserved.}

Corresponding Author: C.J. Malanga, M.D., Ph.D., Department of Neurology, University of North Carolina at Chapel Hill, 170 Manning Dr., CB 7025, Chapel Hill, NC 27599-7025, Tel: (919) 966-1683, Fax: (919) 843-4576, malangacj@ neurology.unc.edu. ${ }^{2}$ Department of Pediatrics, Weill Medical College of Cornell University, The New York Presbyterian Hospital, 525 East $68^{\text {th }}$ St., New York, NY 10021, Tel: (212) 746-3278, Fax: (212) 746-8137, bar2009@med.cornell.edu.

Publisher's Disclaimer: This is a PDF file of an unedited manuscript that has been accepted for publication. As a service to our customers we are providing this early version of the manuscript. The manuscript will undergo copyediting, typesetting, and review of the resulting proof before it is published in its final citable form. Please note that during the production process errors may be discovered which could affect the content, and all legal disclaimers that apply to the journal pertain. 


\section{INTRODUCTION}

Although more than a century of clinical observations have described tolerance to the euphoric effects of cocaine with compulsive use in humans, animal studies consistently show sensitization to its behavioral effects with repeated exposure. Sensitization to the locomotor-stimulating effects of psychostimulants has been suggested as a behavioral mechanism that may model aspects of human drug addiction, particularly drug craving (Robinson and Berridge, 1993). While some studies have differentiated stimulant effects on reward from their effects on learning mechanisms (Chen et al., 2008), fewer have attempted to examine cocaine effects on both operant and Pavlovian behaviors in the same animals, and investigate cellular adaptations occurring in those animals, during the course of repeated cocaine exposure.

Intracranial self-stimulation (ICSS) is an operant behavior in which animals perform a task to deliver electrical stimulation directly to brain reward circuitry (Carlezon and Chartoff, 2007; Kenny, 2007; Kornetsky and Bain, 1992; Olds and Milner, 1954; Wise, 1998). Drugs of abuse, regardless of pharmacological class, potentiate the rewarding value of brain stimulation-reward, or BSR (Kornetsky and Bain, 1992; Kornetsky and Duvauchelle, 1994). Unlike their effects on locomotor behavior, the effects of psychostimulants (Bauco and Wise, 1997; Frank et al., 1988; Gilliss et al., 2002; Kenny et al., 2003; Wise and Munn, 1993) and opioids (Bauco et al., 1993; Esposito and Kornetsky, 1977) on BSR do not appear to sensitize with repeated exposure.

Cocaine exposure alters synthesis and membrane trafficking of AMPA-sensitive glutamate receptor (AMPAR) subunits in an anatomically specific manner. Increased AMPAR function and GluR1 synthesis in dopaminergic neurons of the mesencephalic ventral tegmental area (VTA) are well-characterized early responses to psychostimulants (Carlezon and Nestler, 2002; Churchill et al., 1999; Fitzgerald et al., 1996; Saal et al., 2003; Ungless et al., 2001; White et al., 1995; Zhang et al., 1997) but see (Lu et al., 2002). Repeated noncontingent cocaine exposure and withdrawal increases AMPAR synthesis (Churchill et al., 1999; Lu et al., 2003), surface expression (Boudreau and Wolf, 2005) and function (Pierce et al., 1996) in nucleus accumbens (NAc) medium spiny neurons that reverses upon reexposure to cocaine (Kourrich et al., 2007; Thomas et al., 2001) due to receptor internalization (Boudreau et al., 2007). The transcription factor CRE binding protein (CREB) is a key regulator of cellular processes affecting neuronal excitability and synaptic plasticity in response to drugs of abuse (Carlezon et al., 1998; Dong et al., 2006), and may act in part by regulating expression of glutamate receptor subunits (Olson et al., 2005).

The goal of these experiments was to determine if measurement of locomotor activity and BSR threshold in the same animal could distinguish the effects of repeated, intermittent cocaine exposure on motor behavior and reward processes, respectively. In addition, to determine if BSR leads to similar adaptive changes in neuronal activity we measured expression of proteins involved in glutamatergic transmission (GluR1 and GluR2) and regulation of cellular activity (CREB) in VTA, NAc and dorsolateral striatum (STR), three brain regions implicated in both motor behavior and reward, after repeated ICSS with and without concurrent repeated cocaine exposure.

\section{MATERIALS AND METHODS}

\subsection{Animal Care and Handling}

All experimental animal procedures were carried out according to the NIH Guide to the Care and Use of Laboratory Animals and were approved by the Institutional Animal Care and Use Committee at the University of North Carolina at Chapel Hill. 


\subsection{Intracranial Self-Stimulation (ICSS)}

Sixty-two male white Swiss-Webster mice (Taconic Labs) P50-P60 were anesthetized (ketamine/xylazine 120/18 mg/kg i.p.; Sigma) and stereotaxically implanted with insulated monopolar steel electrodes ( $0.28 \mathrm{~mm}$ diameter; Plastics One, Roanoke VA) to the right median forebrain bundle in the lateral hypothalamus using coordinates from Paxinos and Franklin (1996): bregma $-2.0 \mathrm{~mm}(\mathrm{a} / \mathrm{p})$, sagital $+0.8 \mathrm{~mm}(\mathrm{~m} / \mathrm{l})$ and depth $-4.5 \mathrm{~mm}(\mathrm{~d} / \mathrm{v})$. A steel screw (electrical ground) and the electrode assembly were secured to the skull with dental cement. After recovery mice were individually housed with food and water freely available

Mice were divided into four experimental groups (A, B, C, and D). Groups A and B mice were used for ICSS experiments while Groups C and D mice served as non-ICSS controls (see below). One week after implantation, mice for intracranial self-stimulation (ICSS) experiments (Groups A and B, Figure 1) were trained on a continuous (FR-1) schedule of reinforcement for brain stimulation-reward (BSR) in a $16 \times 14 \times 13 \mathrm{~cm}$ operant chamber with a wheel manipulandum and a house light (MedAssociates, St. Albans VT). Each quarter-turn of the wheel earned a $500 \mathrm{msec}$ train of unipolar cathodal square-wave current at a frequency of $158 \mathrm{~Hz}$ (pulse width $=100 \mu \mathrm{sec}$ ) and activated the house light for 500 msec; subsequent responses during the $500 \mathrm{msec}$ pulse train earned no additional stimulation. Optimal stimulus intensity to sustain responding $\geq 40$ responses/min was determined for each animal $(-90$ to $-220 \mu \mathrm{A})$ and was kept constant for all experiments. Mice were then trained with a series of stimulus frequencies in descending order from 158 $\mathrm{Hz}$ to $19 \mathrm{~Hz}$ in $0.05 \log _{10}$ increments (i.e., $\log _{10}[112 \mathrm{~Hz}]=2.05 ; \log _{10}[100 \mathrm{~Hz}]=2.00$, etc.). At each frequency, five non-contingent priming stimuli were followed by $50 \mathrm{sec}$ FR-1 access to BSR during which responses were measured. A $5 \mathrm{sec}$ time-out period followed each trial frequency during which responses earned no additional stimulation. Mice were trained to complete four series of 15 trial frequencies (i.e., one hour daily). The frequency range was adjusted for each mouse such that only the highest 4-6 frequencies sustained responding. For each series of 15 frequencies, operant response rate for BSR was plotted (i.e., the rate-frequency curve). BSR threshold $\left(\theta_{0}\right)$ defined as the $\mathrm{X}$-intercept of the leastsquares regression line through frequencies that sustained responding at 20,30,40,50, and $60 \%$ of the maximal response rate in each series was calculated automatically by customdesigned software. This determination of reward threshold is less sensitive to changes in response rate than other calculations, e.g., EF50 (Miliaressis et al., 1986). Saline injections began when BSR thresholds varied $< \pm 10 \%$ over three days. During training, sham-ICSS (Group D) mice were placed in the operant chambers, attached to the stimulation apparatus for one hour daily; and spinning the wheel had no consequences; while surgical control (Group C) mice remained in their home cages and were handled daily.

On each test day, three rate-frequency curves were acquired before and four after injection with saline vehicle or cocaine (Sigma). The first series (warm-up) was discarded; $\theta_{0}$ and maximum rate from the second and third rate-frequency curves were averaged and used as daily baselines for each animal. Cocaine $(15 \mathrm{mg} / \mathrm{kg}$ as the free base) was administered in normal saline by intraperitoneal injection. BSR thresholds and maximum response rates were measured for four 15-minute series after cocaine or saline injections and expressed as percent changes from baseline. Group D (novelty control) mice were placed in the ICSS chambers for 45 minutes, injected with saline or cocaine, and returned to the chambers for an additional hour, mimicking testing conditions for ICSS mice (Groups A and B). On experimental day 7, ten ICSS mice (5 each from Groups A and B) and six non-ICSS surgical control mice (Group C) were euthanized and brains were processed for protein determinations. During cocaine abstinence (Days 19-32) Group A and B mice were tested with ICSS and saline injections on alternate days and Group D mice were injected with saline on the same schedule in the ICSS chambers. 


\subsection{Locomotor Behavior}

Locomotion was measured in transparent activity monitoring boxes $(28 \times 28 \mathrm{~cm})$ separated by opaque barriers in a darkened room. Beam breaks of a $16 \times 16$ infrared array were quantified by commercial software (MedAssociates) and expressed as total distance traveled (cm). All mice were placed in the locomotor boxes for 15 minutes (habituation), removed and injected with either saline or cocaine (15 mg/kg i.p. as the free base), immediately returned to the boxes, and monitored for 30 minutes. On experimental day 33 (see Figure 1) locomotor activity was measured in all non-ICSS mice (Groups C and D) and in half of the ICSS mice (Groups A and B) after cocaine challenge (15 mg/kg i.p.); cocaine effects on BSR were measured in the other half of the Group A and B mice. On day 34, locomotor activity was measured after cocaine in the half of Group A and B mice in which ICSS was measured on day 33, and cocaine effects on BSR in the half that were challenged in the locomotor apparatus on day 33. For each animal, locomotor sensitization to cocaine was defined as a greater total distance traveled after cocaine on the last administration of the initiation phase and on challenge than after the first administration in the locomotor apparatus. Mice were euthanized and brains were processed for protein determinations 24 hours after completion of behavioral experiments. Only mice that demonstrated locomotor sensitization were included in the analysis of cocaine and ICSS effects on protein expression.

\subsection{Protein Determinations}

Mice were anesthetized with sodium pentobarbital $(120 \mathrm{mg} / \mathrm{kg})$ and brains were removed, frozen in isopentane $\left(-40^{\circ} \mathrm{C}\right)$, and serially sectioned on a cryostat to the rostral pole of the NAc. A $1.0 \mathrm{~mm}$ slab was cut and bilateral tissue punches were taken from the NAc and STR (18 and 17 gauge, respectively). Punches taken from structures contralateral and ipsilateral to the ICSS electrode were stored separately for the first time point (day 7) and pooled for the second time point (days 34/35; see Figure 1). Sectioning continued to the rostral midbrain where a second $1.0 \mathrm{~mm}$ slab was cut and a single midline punch of the VTA (17 gauge) was taken. Tissues were sonicated in $1 \%$ SDS in TE $(\mathrm{pH}=7.4)$ containing $1 \mathrm{X}$ protease inhibitor cocktail ( $1 \mathrm{mM}$ AEBSF, $0.08 \mu \mathrm{M}$ aprotinin, $21 \mu \mathrm{M}$ leupeptin, $36 \mu \mathrm{M}$ bestatin, $15 \mu \mathrm{M}$ pepstatin A, and $14 \mu \mathrm{M}$ E-64). Samples were centrifuged at 14,000 rpm $\times$ $10 \mathrm{~min}$ and total protein concentrations were determined in supernatants (BCA Assay, Pierce, Rockford, IL). $10.0 \mu$ g protein was run on a $10 \%$ SDS polyacrylamide gel, and transferred to a polyvinylidene fluoride membrane (Immuno-Blot PVDF, $0.2 \mathrm{~mm}$, Bio-Rad Laboratories, Hercules CA). Blots were immersed in blocking buffer (5\% non-fat dried milk in $0.25 \mathrm{M}$ Tris-HCL [pH = 7.6], $1.37 \mathrm{M} \mathrm{NaCl}, 0.1 \%$ Tween) for $60 \mathrm{~min}$ and probed with primary antibody (GluR1: Chemicon, 1:850; GluR2: Chemicon, 1:1,000; CREB: Cell Signaling, 1:500; $\beta$-Actin: Chemicon, 1:2,500) for 16 hours at $4^{\circ} \mathrm{C}$. Blots were washed $4 \times 5$ min. each in blocking buffer and incubated with goat anti-rabbit (1:10,000 for GluR1; 1:5,000 for GluR2 and CREB) or horse anti-mouse (1:20,000 for $\beta$-Actin) horseradish peroxidase-conjugated $\operatorname{IgG}$ (Vector Laboratories, Burlingame $\mathrm{CA}$ ) for 1 hour at room temperature, followed by $1 \times 15 \mathrm{~min}$ and $4 \times 5$ min washes. Protein bands were detected by chemiluminescence (Western Lightning, Perkin Elmer Life Sciences, Boston MA) and exposed to autoradiographic film. Kaleidoscope-prestained standards (Bio-Rad) were used for protein size determination. Anti-GluR1 and anti-GluR2 were detected at $108 \mathrm{kD}$; CREB and $\beta$-Actin at $42 \mathrm{kD}$. Films were scanned for quantification and intensity of protein bands were measured as optical density using ImageJ (v.1.32j; NIH, Bethesda MD).

\subsection{Histology}

During serial sectioning for tissue punches, coronal sections $(50 \mu \mathrm{m})$ were collected through the ICSS electrode tract by thaw-mounting onto subbed slides, stained with cresyl violet for 
Nissl, and electrode placements were confirmed under low-power (4X) light microscopy (Figure 2).

\subsection{Statistical Analysis}

Statistical analyses were performed with SPSS 16.0 for Windows. ANOVA for repeated measures was used to determine effects of ICSS training and serial $\theta_{0}$ determination on total locomotion in mice sacrificed for protein determinations on day 7. For protein measurements, band density of samples from ICSS tissues expressed as percentage of the average optical density of all control bands in each blot were compared with Levene's $F$ test for equality of variances followed by two-tailed $t$-tests for unmatched samples. Because of the crossover design of the concurrent ICSS and locomotion experiments with cocaine (Figure 1), ANOVA for repeated measures could not be applied to these data; three-way ANOVA (experimental group $\times$ day of regimen $\times$ time after injection) was used to determine differences between ICSS and control groups in locomotor behavior and between ICSS groups (A vs. B) in $\theta_{0}$ and maximum operant response rate.

\section{RESULTS}

\subsection{Effect of ICSS on Locomotor Behavior and Protein Expression}

Analysis of locomotion during the saline habituation phase (experimental days 1-6 in Figure 1) showed significant main effects of experimental day (Saline $1-3 ; F_{(2,13)}=16.48, P<$ 0.001 ); but no differences in locomotor behavior between mice that had received ICSS training and concurrent BSR threshold $\left(\theta_{0}\right)$ determinations and control mice (Figure 3 ). Total distance traveled was significantly less in the 30 minutes after saline injection in all mice (PRE vs. POST; $\left.F_{(1,14)}=88.99, P<0.001\right)$; and this habituation did not differ between ICSS mice (Groups A and B; $n=10$ ) and controls (Group C; $n=6$ ). For this subset of 16 mice that were sacrificed on experimental day 8 for protein determinations, there were no significant interactions between experimental day (Saline 1-3), saline injection (PRE vs. POST) or ICSS (vs. non-ICSS controls). Total electrical charge delivery, a function of both stimulus amplitude $(\mu \mathrm{A})$ and stimulus train frequency $(\mathrm{Hz})$, is the most physiologicallyrelevant measure of brain stimulation reward (Gallistel, 1978): baseline pre-injection BSR thresholds expressed as charge $\left(\mathrm{C}\right.$, in Coulombs) at $\theta_{0}$ did not change significantly with daily saline injections over six days in ICSS mice (Saline $1=-5.50 \pm 1.74 \times 10^{-7} \mathrm{C}$; Saline $2=-5.75 \pm 1.82 \times 10^{-7} \mathrm{C}$; Saline $3=-6.17 \pm 1.95 \times 10^{-7} \mathrm{C}$ ).

Total tissue content of the AMPA-type glutamate receptor subunits GluR1 and GluR2 and the transcription factor cAMP response element binding protein (CREB) were measured on experimental day 7. Neither ICSS nor control mice demonstrated significant differences in any protein levels between paired structures (nucleus accumbens, NAc; and dorsolateral striatum, STR) ipsilateral and contralateral to the ICSS electrode placement: densities of ipsilateral and contralateral samples were subsequently averaged. A significant increase in total GluR1 expression (ICSS $=193 \pm 35 \%$ of control, $t=2.60 ; d f=9 ; P<0.05$ ) but no differences in total GluR2 or CREB levels were seen in the ventral tegmental area (VTA) of mice that responded for BSR (Figure 4). There were no significant differences between ICSS mice and controls in the STR (data not shown) or NAc for any proteins measured.

\subsection{Effect of Repeated Acute Cocaine on Locomotion and ICSS}

Repeated acute, intermittent cocaine administration $(15 \mathrm{mg} / \mathrm{kg}$ i.p.) resulted in progressively greater total locomotion in the large majority of mice tested: 20/20 control mice (Groups C and D) and 17/24 ICSS mice (Groups A and B) sensitized to the locomotor-stimulating effect of cocaine (Fisher's Exact Test, ICSS vs. non-ICSS controls, $P<0.05$ ). Initial analysis of sensitized mice from all four experimental groups independently showed 
significant main effects of day of regimen $\left(F_{(9,316)}=18.87, P<0.001\right)$ but no main effect of treatment group or interaction of day and treatment group on total locomotion after cocaine. Sensitized control (Groups C and D) and ICSS mice (Groups A and B) were subsequently pooled and analyzed: A significant effect of day of cocaine regimen $(F(9,316)$ $=20.46, P<0.001)$ but not ICSS, and no interaction between day and ICSS, was found on total locomotion after repeated cocaine (Figure 5). First locomotion measured after cocaine administration (i.e., Cocaine 1 in Group A, Cocaine 2 in Group B) was significantly less $(4360 \pm 701 \mathrm{~cm})$ in the 17/24 ICSS mice that sensitized to cocaine than in the 7/24 ICSS mice that did not demonstrate sensitization $(9785 \pm 1625 \mathrm{~cm} ; t=-3.62 ; d f=22 ; P<0.01$; Figure 5, inset). On the last day of cocaine initiation (Cocaine 5 for Group A; Cocaine 6 for Groups B, C and D; see Figure 1), the 17 sensitized ICSS mice showed an average locomotion of $334 \pm 82 \%$ of their first day of cocaine in the locomotor apparatus (Cocaine 1 for Groups A, C and D; Cocaine 2 for Group B) compared to $417 \pm 160 \%$ of Cocaine 1 in controls $(P=N S)$. On cocaine challenge, total locomotion was $298 \pm 72 \%$ of first cocaine in ICSS mice compared to $380 \pm 129 \%$ of cocaine 1 in controls $(P=N S)$. The seven ICSS mice that did not sensitize to repeated cocaine uniformly showed interval decreases in total locomotion between the first day of cocaine and both the last day of initiation $(39 \pm 7 \%$ of first cocaine) and challenge ( $36 \pm 11 \%$ of first cocaine).

Representative ICSS rate-frequency curves are shown in Figure 6A. Daily baseline preinjection BSR threshold expressed as charge delivery at $\theta_{0}$ did not change significantly over 34 days of the repeated cocaine regimen in ICSS mice (Figure 6B). In the overall three-way ANOVA (group $[\mathrm{A} / \mathrm{B}] \times$ treatment day $\times$ time after injection) significant main effects of day of regimen $\left(F_{(14,95)}=32.28, P<0.001\right)$ and time after injection $\left(F_{(3,95)}=28.22, P<\right.$ 0.001 ) on changes in $\theta_{0}$ to acute cocaine were seen (Figure 6C). No difference in $\theta_{0}$ changes after saline or cocaine injection (15 mg/kg i.p.) was seen between Group A and Group B mice, and no significant interactions between these variables were found. Post-hoc Tukey's tests showed that all cocaine days (Cocaine 1-6 and Challenge) differed significantly from all saline days (Tukey's HSD $P<0.001$ for all comparisons), and that no saline days or cocaine days differed from each other. A significant main effect of day of regimen $\left(F_{(14,95)}\right.$ $=2.01, P<0.05)$ on maximum operant response rate was also observed; however, post-hoc Tukey's tests did not support a significant effect of treatment day (Figure 6D). No significant differences in maximum operant response rate after either saline or cocaine injections were seen between Group A and Group B mice.

\subsection{Effects of ICSS and Repeated Acute Cocaine on Protein Expression}

After completion of behavioral experiments, total GluR1, GluR2, and CREB levels in the VTA, NAc, and STR from sensitized mice were measured. There were no significant differences between Groups A $(n=3)$ and $\mathrm{B}(n=5)$ or between Groups C $(n=6)$ and $\mathrm{D}(n=$ 5 ) for any of the three proteins examined in any region; values for ICSS mice (Groups A and B) and non-ICSS controls (Groups C and D) were subsequently averaged. Total GluR1 expression remained elevated in the VTA of ICSS mice but was not significantly greater than non-ICSS controls (ICSS $=149 \pm 60 \%$ of control; Figure 7, bottom left). No differences in GluR2 or CREB levels were seen in the VTA. In the NAc both GluR1 (ICSS $=44 \pm 4 \%$ of control, $t=-2.21 ; d f=17 ; P<0.05$ ) and GluR2 (ICSS $=53 \pm 5 \%$ of control, $t=-2.78$; $d f=12 ; P<0.02)$ but not CREB were significantly lower in ICSS mice than in non-ICSS controls after cocaine (Figure 7, top). There were no significant differences in the STR between ICSS mice and controls for any proteins measured (data not shown).

Optical densities (OD) for GluR1, GluR2 and CREB bands normalized to $\beta$-Actin OD in the same lanes were compared between western blots of samples from non-ICSS control subjects before (i.e., day 7; Group C, $n=6$ ) and after cocaine challenge (Groups $\mathrm{C}$ and $\mathrm{D}, n$ $=11$ ). No significant differences were found between protein measurements from Group C 
and D mice after cocaine challenge, and values were subsequently averaged. In the VTA, GluR2: $\beta$-Actin OD ratios were significantly greater in mice 24 hours after cocaine challenge than in saline-treated mice on day $7(t=-3.04 ; d f=15 ; P<0.01)$, while non-significant increases in GluR1: $\beta$-Actin and decreases in CREB: $\beta$-Actin were seen (Table 1, top). In the NAc, GluR1: $\beta$-Actin $(t=2.10 ; d f=15 ; P<0.05)$, GluR2: $\beta$-Actin $(t=3.75 ; d f=5 ; P<$ $0.02)$ and CREB: $\beta$-Actin $(t=4.83 ; d f=13 ; P<0.01)$ were all significantly lower in samples from mice after cocaine challenge (Table 1, bottom).

\section{DISCUSSION}

Since its development in initial studies of physiological and anatomical substrates of brain reward over fifty years ago (Olds and Milner, 1954), intracranial self-stimulation (ICSS) has been used to investigate mechanisms underlying the rewarding effects of drugs of abuse (Kornetsky and Bain, 1992; Wise, 1996). One consistent observation in ICSS studies has been the stability of brain stimulation-reward (BSR) to the reward-potentiating effects of repeated psychostimulant administration, to which neither tolerance nor sensitization appear to develop (Bauco and Wise, 1997; Frank et al., 1988; Gilliss et al., 2002; Kenny et al., 2003; Wise and Munn, 1993). We found that repeated acute cocaine administration sensitized mice to its effects on locomotion but not its reward-potentiating effect on BSR measured in the same animals. Baseline reward thresholds did not change over the course of locomotor sensitization; and increased total locomotion did not affect performance of the operant task. We found no conditioned potentiation of BSR after repeated drug injection (Kenny et al., 2003; Kokkinidis and Zacharko, 1980); that is, saline injections following cocaine had no effect on ICSS performance or BSR thresholds consistent with a Pavlovian conditioned response; nor did we observe elevations in baseline BSR thresholds during the withdrawal phase of the experiment suggesting a generalized decrease in brain reward function (Ahmed et al., 2002; Stoker and Markou, 2011). ICSS experiments in rats (Wise and Munn, 1993) supported similar conclusions, that locomotor sensitization to amphetamine was not associated with changes in its reward-potentiating effect; but because of the long duration of action of amphetamine these measures were taken in series rather than in parallel; and the locomotor sensitization observed was modest at the dose used. However, when locomotor activity was measured concurrently with operant intravenous cocaine self-administration in rats (Koeltzow and Vezina, 2005) no locomotor sensitization was evident until after extinction and cocaine-primed reinstatement, after which both operant responding and total locomotion were significantly increased. We conclude from our data that the processes underlying enhanced motor behavior following repeated, behaviorally non-contingent cocaine administration are dissociable from those mediating the rewarding potency of cocaine in mice.

ICSS differs from drug self-administration in at least three important respects. First, satiety does not develop for BSR. Unlike BSR, drug reward is followed by a consummatory behavioral phase, which may include stimulated locomotor activity and during which mechanisms of satiety engage to decrease motivational drive (Wise et al., 1995). Second, in contrast to drug self-administration, where animals will work more to obtain a devalued reward on a fixed-ratio of reinforcement (Hubner and Moreton, 1991; Yokel and Wise, 1975), devaluing BSR uniformly decreases operant responding to obtain it. Third, in ICSS drug delivery is behaviorally non-contingent, i.e., investigator-administered; therefore the rewarding effects of drugs are measured independent of the motivation of the animal to seek or consume them.

Repeated non-contingent administration of cocaine or amphetamine robustly sensitizes rats to their locomotor stimulating effects and ability to support conditioned place-preference (Lett, 1989; Nocjar and Panksepp, 2002; Shippenberg and Heidbreder, 1995), but only 
modestly increases subsequent intravenous cocaine (Childs et al., 2006; Horger et al., 1990; Schenk and Partridge, 2000) or amphetamine self-administration (Lorrain et al., 2000; Mendrek et al., 1998; Piazza et al., 1990; Pierre and Vezina, 1997). Specifically, noncontingent cocaine @ @ preexposure does not increase break points on progressive ratio schedules of cocaine reinforcement (Childs et al., 2006), suggesting that the rewarding potency of cocaine is unchanged (Richardson and Roberts, 1996). While cocaine selfadministration can result in locomotor sensitization in rats (Ben-Shahar et al., 2005; Knackstedt and Kalivas, 2007; Phillips and Di Ciano, 1996) and mice (Zapata et al., 2003), tolerance has also been observed; particularly after longer or more frequent access or with escalating cocaine intake (Ahmed and Cador, 2006; Ben-Shahar et al., 2004; Lack et al., 2008; Lecca et al., 2007). While concurrent measurements of BSR threshold and cocaine self-administration in mice would be desirable to measure its rewarding potency over time, and could be paired with activity measurements, such experiments are technically prohibitive due to issues of long-term intravenous catheter patency. Our data suggest that repeated non-contingent cocaine exposure increases behavioral activation but does not change the absolute magnitude of cocaine reward in mice. This conclusion, which considers drug-seeking behaviors independently from drug reward, is broadly consistent with recent interpretations of the incentive sensitization theory of addiction forwarded by Robinson and Berridge (2008).

The physiological and anatomical bases of ICSS have been extensively investigated (Wise, 2005), but few studies have examined if or how cellular adaptations occur with ICSS similar to those that occur with cocaine and other drugs of abuse (Hyman and Nestler, 1996; Kalivas and Volkow, 2005). This is relevant not only in the context of behavioral reinforcement, but also to molecular changes that may occur with chronic electrical stimulation of other discrete neural circuits, such as in therapeutic deep-brain stimulation for the treatment of movement disorders or neuropsychiatric diseases (Henning et al., 2007; Schulte et al., 2006). Carlezon et al. (2001) showed that ICSS decreased GluR1 expression but did not change GluR2 in the rat VTA, a finding hypothesized to underlie the insensitivity of BSR to drug sensitization (Carlezon and Nestler, 2002). In contrast, we found that ICSS alone increased GluR1 expression in the mouse VTA, suggesting that VTA neurons may initially adapt to BSR in manner similar to drug or other rewards. Notably, our study and that of Carlezon et al. differed significantly in the duration and intensity of daily ICSS, i.e. alternate-day rate-frequency BSR threshold determinations for 34 days versus daily one-hour ad libitum access to suprathreshold BSR for nine consecutive days.

We found that a sensitizing cocaine regimen decreased both GluR1 and GluR2 expression in the NAc, and extended those findings to show that this effect was greater in mice that selfadministered BSR, suggesting that the two reinforcers may be additive in their ability to induce adaptive changes in glutamatergic sensitivity in the NAc. Interestingly, another study (Levy et al., 2007) demonstrated GluR1 increases in VTA and decreases in NAc after a similar cocaine sensitization regimen in rats, both of which were prevented by noncontingent intracranial electrical stimulation of the lateral hypothalamus, which alone resulted in measurable but non-significant GluR1 increases in VTA and decreases in NAc. Manipulation of GluR1 and GluR2 in the NAc has opposite effects on BSR threshold; that is, overexpression of GluR2 lowers and overexpression of GluR1 raises BSR threshold (Todtenkopf et al., 2006). While we saw no changes in baseline BSR thresholds over the course of the experiment, we did see reductions in both GluR1 and GluR2 in the NAc consistent with sensitization, depression of excitatory neurotransmission and LTD after repeated cocaine exposure (Bachtell et al., 2008; Thomas et al., 2001; Thomas et al., 2000), which was further enhanced by ICSS. However, our results are not necessarily directly comparable to others that have shown different molecular adaptations with either forced drug abstinence (Lu et al., 2003) or extinction training (Sutton et al., 2003) after cocaine 
self-administration, because in our studies BSR, not cocaine, is the operant reinforcer; and cocaine administration is behaviorally non-contingent.

Drugs of abuse induce adaptations in neural function in part by changing expression of genes regulated by CREB activated through phosphorylation (pCREB) by MAPK/ERK and cAMP/PKA signaling pathways in the NAc. Transgenic mice lacking normal CREB demonstrate greater cocaine CPP (Walters and Blendy, 2001) and locomotor sensitization (Sakai et al., 2002), and increased potentiation of BSR by cocaine (Dinieri et al., 2009). Transiently decreasing CREB function in rats by viral overexpression of a dominantnegative mutant protein (mCREB) in the NAc also increases cocaine CPP (Carlezon et al., 1998), lowers baseline BSR threshold (Dinieri et al., 2009); and decreases excitability of NAc medium spiny neurons (Dong et al., 2006), findings all consistent with increased brain reward. We found that CREB levels in the VTA, striatum, and NAc were insensitive to ICSS but were significantly decreased in the NAc after repeated cocaine exposure. It is possible that this decrease may not be functionally significant given the relative levels of constitutively-expressed CREB in the NAc versus the VTA. This is supported by the observation that mutant mice $\left(\mathrm{CREB}^{\alpha \Delta}\right)$ lacking $80-90 \%$ of normal CREB function still respond to drug stimuli with elevations in pCREB and changes in pCREB-mediated gene expression in the NAc but not the VTA, where CREB levels may be limiting (Walters et al., 2003).

The ability to analyze changes in reward perception separately from changes in appetitive behavior with animal models is an important step toward understanding the neurobiological adaptations that occur with repeated exposure to drugs of abuse, and toward targeting therapeutics specific to each process. While broadly consistent with incentive sensitization theories of addiction, our findings do not preclude hedonic allostasis models (Koob and Le Moal, 2008) in which reward perception would be expected to change with repeated drug exposure and withdrawal, which may be the case for heroin (Kenny et al., 2006) or alcohol (Schulteis and Liu, 2006; Schulteis et al., 1995), or for significantly higher chronic doses (Stoker and Markou, 2011) or escalated self-administration of cocaine (Ahmed et al., 2002). Further study of patterns of drug intake and their effects on brain reward using geneticallyengineered mouse models predictive of susceptibility will be particularly informative in this regard. These findings also provide a foundation for mouse experiments in which individual molecular functions are manipulated in a site-specific manner to dissect further the distinction between the behaviorally-activating and rewarding properties of cocaine and other drugs of abuse.

\section{HIGHLIGHTS}

- Locomotor activity but not brain stimulation-reward sensitizes to repeated cocaine.

Intracranial self-stimulation (ICSS) alone increases GluR1 expression in the VTA.

- Repeated cocaine reduces GluR1, GluR2 and CREB in the nucleus accumbens (NAc).

- GluR1 and GluR2, but not CREB, are further reduced in the NAc by cocaine plus ICSS. 


\section{Acknowledgments}

The authors are very grateful to Dr. Anjali Rajadhyaksha, Dr. Thomas Kash, and Dr. Garret Stuber for their advice and helpful comments in the preparation of this manuscript. This work was funded by grants from the National Institute on Drug Abuse, DA015429 (CJM); DA000354 (BEK); and DA008648 (BEK).

\section{REFERENCES}

Ahmed SH, Cador M. Dissociation of psychomotor sensitization from compulsive cocaine consumption. Neuropsychopharmacology. 2006; 31:563-571. [PubMed: 16034440]

Ahmed SH, Kenny PJ, Koob GF, Markou A. Neurobiological evidence for hedonic allostasis associated with escalating cocaine use. Nat Neurosci. 2002; 5:625-626. [PubMed: 12055635]

Bachtell RK, Choi KH, Simmons DL, Falcon E, Monteggia LM, Neve RL, Self DW. Role of GluR1 expression in nucleus accumbens neurons in cocaine sensitization and cocaine-seeking behavior. Eur J Neurosci. 2008; 27:2229-2240. [PubMed: 18430032]

Bauco P, Wang Y, Wise RA. Lack of sensitization or tolerance to the facilitating effect of ventral tegmental area morphine on lateral hypothalamic brain stimulation reward. Brain Res. 1993; 617:303-308. [PubMed: 8402158]

Bauco P, Wise RA. Synergistic effects of cocaine with lateral hypothalamic brain stimulation reward: lack of tolerance or sensitization. J Pharmacol Exp Ther. 1997; 283:1160-1167. [PubMed: 9399989]

Ben-Shahar O, Ahmed SH, Koob GF, Ettenberg A. The transition from controlled to compulsive drug use is associated with a loss of sensitization. Brain Res. 2004; 995:46-54. [PubMed: 14644470]

Ben-Shahar O, Moscarello JM, Jacob B, Roarty MP, Ettenberg A. Prolonged daily exposure to i.v. cocaine results in tolerance to its stimulant effects. Pharmacol Biochem Behav. 2005; 82:411-416. [PubMed: 16253318]

Boudreau AC, Reimers JM, Milovanovic M, Wolf ME. Cell surface AMPA receptors in the rat nucleus accumbens increase during cocaine withdrawal but internalize after cocaine challenge in association with altered activation of mitogen-activated protein kinases. J Neurosci. 2007; 27:10621-10635. [PubMed: 17898233]

Boudreau AC, Wolf ME. Behavioral sensitization to cocaine is associated with increased AMPA receptor surface expression in the nucleus accumbens. J Neurosci. 2005; 25:9144-9151. [PubMed: 16207873]

Carlezon WA Jr, Chartoff EH. Intracranial self-stimulation (ICSS) in rodents to study the neurobiology of motivation. Nat Protoc. 2007; 2:2987-2995. [PubMed: 18007634]

Carlezon WA Jr, Nestler EJ. Elevated levels of GluR1 in the midbrain: a trigger for sensitization to drugs of abuse? Trends Neurosci. 2002; 25:610-615. [PubMed: 12446127]

Carlezon WA Jr, Thome J, Olson VG, Lane-Ladd SB, Brodkin ES, Hiroi N, Duman RS, Neve RL, Nestler EJ. Regulation of cocaine reward by CREB. Science. 1998; 282:2272-2275. [PubMed: 9856954]

Carlezon WA Jr, Todtenkopf MS, McPhie DL, Pimentel P, Pliakas AM, Stellar JR, Trzcinska M. Repeated exposure to rewarding brain stimulation downregulates GluR1 expression in the ventral tegmental area. Neuropsychopharmacology. 2001; 25:234-241. [PubMed: 11425507]

Chen BT, Bowers MS, Martin M, Hopf FW, Guillory AM, Carelli RM, Chou JK, Bonci A. Cocaine but not natural reward self-administration nor passive cocaine infusion produces persistent LTP in the VTA. Neuron. 2008; 59:288-297. [PubMed: 18667156]

Childs E, Shoaib M, Stolerman IP. Cocaine self-administration in rats with histories of cocaine exposure and discrimination. Psychopharmacology (Berl). 2006; 186:168-176. [PubMed: 16596400]

Churchill L, Swanson CJ, Urbina M, Kalivas PW. Repeated cocaine alters glutamate receptor subunit levels in the nucleus accumbens and ventral tegmental area of rats that develop behavioral sensitization. J Neurochem. 1999; 72:2397-2403. [PubMed: 10349849]

Dinieri JA, Nemeth CL, Parsegian A, Carle T, Gurevich VV, Gurevich E, Neve RL, Nestler EJ, Carlezon WA Jr. Altered sensitivity to rewarding and aversive drugs in mice with inducible 
disruption of cAMP response element-binding protein function within the nucleus accumbens. $\mathbf{J}$ Neurosci. 2009; 29:1855-1859. [PubMed: 19211892]

Dong Y, Green T, Saal D, Marie H, Neve R, Nestler EJ, Malenka RC. CREB modulates excitability of nucleus accumbens neurons. Nat Neurosci. 2006; 9:475-477. [PubMed: 16520736]

Esposito R, Kornetsky C. Morphine lowering of self-stimulation thresholds: lack of tolerance with long-term administration. Science. 1977; 195:189-191. [PubMed: 831268]

Fitzgerald LW, Ortiz J, Hamedani AG, Nestler EJ. Drugs of abuse and stress increase the expression of GluR1 and NMDAR1 glutamate receptor subunits in the rat ventral tegmental area: common adaptations among cross-sensitizing agents. J Neurosci. 1996; 16:274-282. [PubMed: 8613793]

Frank RA, Martz S, Pommering T. The effect of chronic cocaine on self-stimulation train-duration thresholds. Pharmacol Biochem Behav. 1988; 29:755-758. [PubMed: 3413201]

Gallistel CR. Self-stimulation in the rat: quantitative characteristics of the reward pathway. J Comp Physiol Psychol. 1978; 92:977-998. [PubMed: 755062]

Gilliss B, Malanga CJ, Pieper JO, Carlezon WA Jr. Cocaine and SKF-82958 potentiate brain stimulation reward in Swiss-Webster mice. Psychopharmacology (Berl). 2002; 163:238-248. [PubMed: 12202971]

Henning J, Koczan D, Glass A, Karopka T, Pahnke J, Rolfs A, Benecke R, Gimsa U. Deep brain stimulation in a rat model modulates TH, CaMKIIa and Homer1 gene expression. Eur J Neurosci. 2007; 25:239-250. [PubMed: 17241285]

Horger BA, Shelton K, Schenk S. Preexposure sensitizes rats to the rewarding effects of cocaine. Pharmacol Biochem Behav. 1990; 37:707-711. [PubMed: 2093176]

Hubner CB, Moreton JE. Effects of selective D1 and D2 dopamine antagonists on cocaine selfadministration in the rat. Psychopharmacology (Berl). 1991; 105:151-156. [PubMed: 1839063]

Hyman SE, Nestler EJ. Initiation and adaptation: a paradigm for understanding psychotropic drug action. Am J Psychiatry. 1996; 153:151-162. [PubMed: 8561194]

Kalivas PW, Volkow ND. The neural basis of addiction: a pathology of motivation and choice. Am J Psychiatry. 2005; 162:1403-1413. [PubMed: 16055761]

Kenny PJ. Brain reward systems and compulsive drug use. Trends Pharmacol Sci. 2007; 28:135-141. [PubMed: 17276521]

Kenny PJ, Chen SA, Kitamura O, Markou A, Koob GF. Conditioned withdrawal drives heroin consumption and decreases reward sensitivity. J Neurosci. 2006; 26:5894-5900. [PubMed: 16738231]

Kenny PJ, Koob GF, Markou A. Conditioned facilitation of brain reward function after repeated cocaine administration. Behav Neurosci. 2003; 117:1103-1107. [PubMed: 14570559]

Knackstedt LA, Kalivas PW. Extended access to cocaine self-administration enhances drug-primed reinstatement but not behavioral sensitization. J Pharmacol Exp Ther. 2007; 322:1103-1109. [PubMed: 17601982]

Koeltzow TE, Vezina P. Locomotor activity and cocaine-seeking behavior during acquisition and reinstatement of operant self-administration behavior in rats. Behav Brain Res. 2005; 160:250 259. [PubMed: 15863221]

Kokkinidis L, Zacharko RM. Enhanced self-stimulation responding from the substantia nigra after chronic amphetamine treatment: a role for conditioning factors. Pharmacol Biochem Behav. 1980; 12:543-547. [PubMed: 7393951]

Koob GF, Le Moal M. Neurobiological mechanisms for opponent motivational processes in addiction. Philos Trans R Soc Lond B Biol Sci. 2008; 363:3113-3123. Review. [PubMed: 18653439]

Kornetsky C, Bain G. Brain-stimulation reward: a model for the study of the rewarding effects of abused drugs. NIDA Res Monogr. 1992; 124:73-93. [PubMed: 1470216]

Kornetsky C, Duvauchelle C. Dopamine, a common substrate for the rewarding effects of brain stimulation reward, cocaine, and morphine. NIDA Res Monogr. 1994; 145:19-39. [PubMed: 8742806]

Kourrich S, Rothwell PE, Klug JR, Thomas MJ. Cocaine experience controls bidirectional synaptic plasticity in the nucleus accumbens. J Neurosci. 2007; 27:7921-7928. [PubMed: 17652583] 
Lack CM, Jones SR, Roberts DC. Increased breakpoints on a progressive ratio schedule reinforced by IV cocaine are associated with reduced locomotor activation and reduced dopamine efflux in nucleus accumbens shell in rats. Psychopharmacology (Berl). 2008; 195:517-525. [PubMed: 17879088]

Lecca D, Cacciapaglia F, Valentini V, Acquas E, Di Chiara G. Differential neurochemical and behavioral adaptation to cocaine after response contingent and noncontingent exposure in the rat. Psychopharmacology (Berl). 2007; 191:653-667. [PubMed: 16932924]

Lett BT. Repeated exposures intensify rather than diminish the rewarding effects of amphetamine, morphine, and cocaine. Psychopharmacology (Berl). 1989; 98:357-362. [PubMed: 2546170]

Levy D, Shabat-Simon M, Shalev U, Barnea-Ygael N, Cooper A, Zangen A. Repeated electrical stimulation of reward-related brain regions affects cocaine but not "natural" reinforcement. J Neurosci. 2007; 27:14179-14189. [PubMed: 18094257]

Lorrain DS, Arnold GM, Vezina P. Previous exposure to amphetamine increases incentive to obtain the drug: long-lasting effects revealed by the progressive ratio schedule. Behav Brain Res. 2000; 107:9-19. [PubMed: 10628726]

Lu L, Grimm JW, Shaham Y, Hope BT. Molecular neuroadaptations in the accumbens and ventral tegmental area during the first 90 days of forced abstinence from cocaine self-administration in rats. J Neurochem. 2003; 85:1604-1613. [PubMed: 12787079]

Lu W, Monteggia LM, Wolf ME. Repeated administration of amphetamine or cocaine does not alter AMPA receptor subunit expression in the rat midbrain. Neuropsychopharmacology. 2002; 26:113. [PubMed: 11751027]

Mendrek A, Blaha CD, Phillips AG. Pre-exposure of rats to amphetamine sensitizes selfadministration of this drug under a progressive ratio schedule. Psychopharmacology (Berl). 1998; 135:416-422. [PubMed: 9539267]

Miliaressis E, Rompre PP, Laviolette P, Philippe L, Coulombe D. The curve-shift paradigm in selfstimulation. Physiol Behav. 1986; 37:85-91. [PubMed: 3016774]

Nocjar C, Panksepp J. Chronic intermittent amphetamine pretreatment enhances future appetitive behavior for drug- and natural-reward: interaction with environmental variables. Behav Brain Res. 2002; 128:189-203. [PubMed: 11796164]

Olds J, Milner P. Positive reinforcement produced by electrical stimulation of septal area and other regions of rat brain. J Comp Physiol Psychol. 1954; 47:419-427. [PubMed: 13233369]

Olson VG, Zabetian CP, Bolanos CA, Edwards S, Barrot M, Eisch AJ, Hughes T, Self DW, Neve RL, Nestler EJ. Regulation of drug reward by cAMP response element-binding protein: evidence for two functionally distinct subregions of the ventral tegmental area. J Neurosci. 2005; 25:55535562. [PubMed: 15944383]

Paxinos, GT.; Franklin, KB. The Mouse Brain in Stereotaxic Coordinates. San Diego: Academic Press; 1996.

Phillips AG, Di Ciano P. Behavioral sensitization is induced by intravenous self-administration of cocaine by rats. Psychopharmacology (Berl). 1996; 124:279-281. [PubMed: 8740051]

Piazza PV, Deminiere JM, le Moal M, Simon H. Stress- and pharmacologically-induced behavioral sensitization increases vulnerability to acquisition of amphetamine self-administration. Brain Res. 1990; 514:22-26. [PubMed: 2357527]

Pierce RC, Bell K, Duffy P, Kalivas PW. Repeated cocaine augments excitatory amino acid transmission in the nucleus accumbens only in rats having developed behavioral sensitization. $\mathrm{J}$ Neurosci. 1996; 16:1550-1560. [PubMed: 8778304]

Pierre PJ, Vezina P. Predisposition to self-administer amphetamine: the contribution of response to novelty and prior exposure to the drug. Psychopharmacology (Berl). 1997; 129:277-284. [PubMed: 9084067]

Richardson NR, Roberts DC. Progressive ratio schedules in drug self-administration studies in rats: a method to evaluate reinforcing efficacy. J Neurosci Methods. 1996; 66:1-11. [PubMed: 8794935]

Robinson TE, Berridge KC. The neural basis of drug craving: an incentive-sensitization theory of addiction. Brain Res Brain Res Rev. 1993; 18:247-291. [PubMed: 8401595]

Robinson TE, Berridge KC. The incentive sensitization theory of addiction: some current issues. Philos Trans R Soc Lond B Biol Sci. 2008; 363:3137-3146. Review. [PubMed: 18640920] 
Saal D, Dong Y, Bonci A, Malenka RC. Drugs of abuse and stress trigger a common synaptic adaptation in dopamine neurons. Neuron. 2003; 37:577-582. [PubMed: 12597856]

Sakai N, Thome J, Newton SS, Chen J, Kelz MB, Steffen C, Nestler EJ, Duman RS. Inducible and brain region-specific CREB transgenic mice. Mol Pharmacol. 2002; 61:1453-1464. [PubMed: 12021407]

Schenk S, Partridge B. Sensitization to cocaine's reinforcing effects produced by various cocaine pretreatment regimens in rats. Pharmacol Biochem Behav. 2000; 66:765-770. [PubMed: 10973514]

Schulte T, Brecht S, Herdegen T, Illert M, Mehdorn HM, Hamel W. Induction of immediate early gene expression by high-frequency stimulation of the subthalamic nucleus in rats. Neuroscience. 2006; 138:1377-1385. [PubMed: 16460881]

Schulteis G, Liu J. Brain reward deficits accompany withdrawal (hangover) from acute ethanol in rats. Alcohol. 2006; 39:21-28. [PubMed: 16938626]

Schulteis G, Markou A, Cole M, Koob GF. Decreased brain reward produced by ethanol withdrawal. Proc Natl Acad Sci U S A. 1995; 92:5880-5884. [PubMed: 7597046]

Shippenberg TS, Heidbreder C. Sensitization to the conditioned rewarding effects of cocaine: pharmacological and temporal characteristics. J Pharmacol Exp Ther. 1995; 273:808-815. [PubMed: 7752084]

Stoker AK, Markou A. Withdrawal from chronic cocaine administration induces deficits in brain reward function in C57BL/6J mice. Behav Brain Res. 2011; 223:176-181. [PubMed: 21557971]

Sutton MA, Schmidt EF, Choi KH, Schad CA, Whisler K, Simmons D, Karanian DA, Monteggia LM, Neve RL, Self DW. Extinction-induced upregulation in AMPA receptors reduces cocaine-seeking behaviour. Nature. 2003; 421:70-75. [PubMed: 12511956]

Thomas MJ, Beurrier C, Bonci A, Malenka RC. Long-term depression in the nucleus accumbens: a neural correlate of behavioral sensitization to cocaine. Nat Neurosci. 2001; 4:1217-1223. [PubMed: 11694884]

Thomas MJ, Malenka RC, Bonci A. Modulation of long-term depression by dopamine in the mesolimbic system. J Neurosci. 2000; 20:5581-5586. [PubMed: 10908594]

Todtenkopf MS, Parsegian A, Naydenov A, Neve RL, Konradi C, Carlezon WA Jr. Brain reward regulated by AMPA receptor subunits in nucleus accumbens shell. J Neurosci. 2006; 26:1166511669. [PubMed: 17093088]

Ungless MA, Whistler JL, Malenka RC, Bonci A. Single cocaine exposure in vivo induces long-term potentiation in dopamine neurons. Nature. 2001; 411:583-587. [PubMed: 11385572]

Walters CL, Blendy JA. Different requirements for cAMP response element binding protein in positive and negative reinforcing properties of drugs of abuse. J Neurosci. 2001; 21:9438-9444. [PubMed: 11717377]

Walters CL, Kuo YC, Blendy JA. Differential distribution of CREB in the mesolimbic dopamine reward pathway. J Neurochem. 2003; 87:1237-1244. [PubMed: 14622103]

White FJ, Hu XT, Zhang XF, Wolf ME. Repeated administration of cocaine or amphetamine alters neuronal responses to glutamate in the mesoaccumbens dopamine system. J Pharmacol Exp Ther. 1995; 273:445-454. [PubMed: 7714800]

Wise RA. Addictive drugs and brain stimulation reward. Annu Rev Neurosci. 1996; 19:319-340. [PubMed: 8833446]

Wise RA. Drug-activation of brain reward pathways. Drug Alcohol Depend. 1998; 51:13-22. [PubMed: 9716927]

Wise RA. Forebrain substrates of reward and motivation. J Comp Neurol. 2005; 493:115-121. [PubMed: 16254990]

Wise RA, Munn E. Effects of repeated amphetamine injections on lateral hypothalamic brain stimulation reward and subsequent locomotion. Behav Brain Res. 1993; 55:195-201. [PubMed: 8357528]

Wise RA, Newton P, Leeb K, Burnette B, Pocock D, Justice JB Jr. Fluctuations in nucleus accumbens dopamine concentration during intravenous cocaine self-administration in rats.

Psychopharmacology (Berl). 1995; 120:10-20. [PubMed: 7480530] 
Yokel RA, Wise RA. Increased lever pressing for amphetamine after pimozide in rats: implications for a dopamine theory of reward. Science. 1975; 187:547-549. [PubMed: 1114313]

Zapata A, Chefer VI, Ator R, Shippenberg TS, Rocha BA. Behavioural sensitization and enhanced dopamine response in the nucleus accumbens after intravenous cocaine self-administration in mice. Eur J Neurosci. 2003; 17:590-596. [PubMed: 12581176]

Zhang XF, Hu XT, White FJ, Wolf ME. Increased responsiveness of ventral tegmental area dopamine neurons to glutamate after repeated administration of cocaine or amphetamine is transient and selectively involves AMPA receptors. J Pharmacol Exp Ther. 1997; 281:699-706. [PubMed: 9152375] 


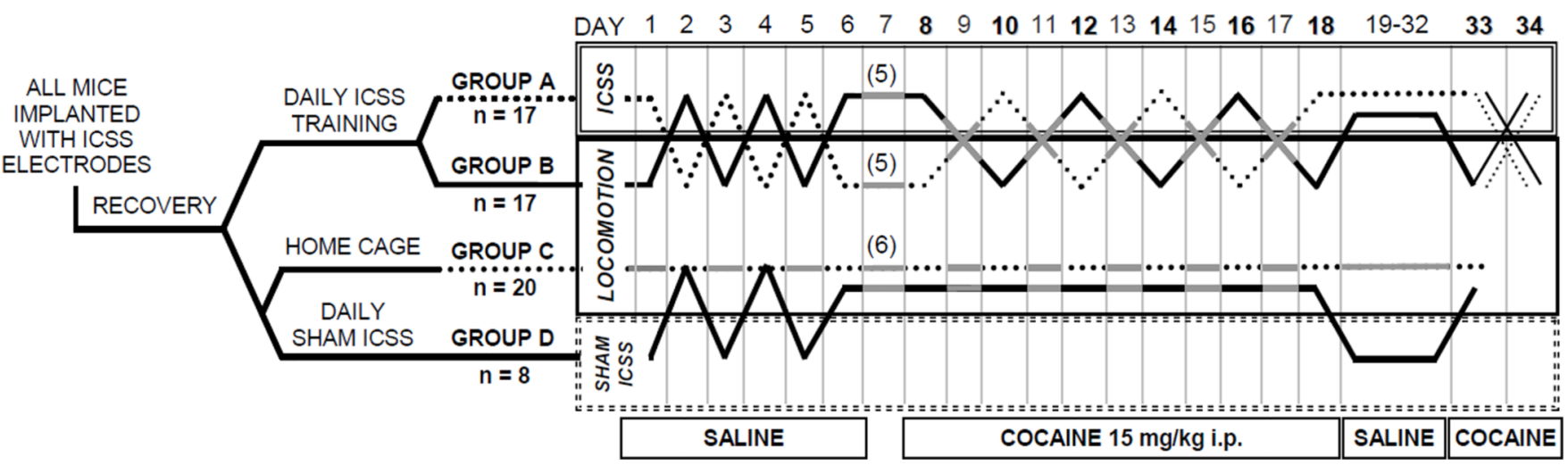

Figure 1.

Diagram of the experimental design for alternating measurement of intracranial selfstimulation (ICSS) and locomotion in mice habituated to saline injections (days 1-6) and given a repeated cocaine regimen (days 8-18) followed by withdrawal (days 19-32) and cocaine challenge. For example, Group A mice received saline and ICSS was measured on Day 1; received saline and locomotion was measured on Day 2; etc. ICSS mice (Groups A and $\mathrm{B}$ ) received saline and ICSS was measured every other day during cocaine withdrawal (days 19-32). Cocaine challenge (15 mg/kg i.p.) was measured in half of Group A and Group B mice with ICSS on day 33 and with locomotor activity on day 34; the other half were challenged with locomotion measurement (day 33) then ICSS (day 34). Solid grey lines (days 7, 9, etc.) indicate experimental days that mice remained in their home cages. Days numbered in bold (days 8,10 , etc.) indicate experiments in which mice received cocaine. Numbers in parentheses on day 7 indicate mice removed from the protocol for protein determinations shown in Figure 3. See Materials and Methods for details. 


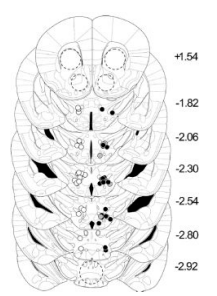

Figure 2.

ICSS electrode placements in the medial forebrain bundle at the level of the lateral hypothalamus. Electrode tip locations are plotted on templates from the standard mouse stereotaxic atlas (Paxinos and Franklin, 1996) by manual inspection of Nissl-stained sections. All electrodes were implanted on the right; control mice (white circles = non-/sham ICSS; Groups C and D; $n=28$ ) are shown on the left for clarity. Black circles $=$ ICSS mice (Groups A and B; $n=34)$; gray circles = non-sensitizing ICSS mice $(n=7)$. Locations of tissue punches (dashed circles) are indicated in the nucleus accumbens (NAc; 18 gauge), dorsolateral striatum (STR; 17 gauge) and ventral tegmental area (VTA; 17 gauge). 


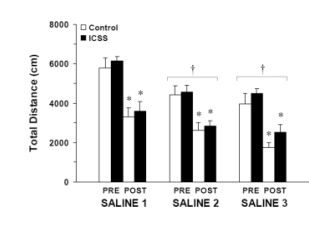

Figure 3.

Changes in locomotion over 30 minutes after i.p. saline injection $(\times 3)$ on alternate days.

Values at each time point are plotted as mean distance traveled (in $\mathrm{cm}) \pm$ S.E.M. White bars

$=$ control mice (Group C; $n=6$ ); black bars = ICSS mice (Groups A and B; $n=10$; see

Figure 1). No differences between ICSS and control mice were found (see Results).

Tukey's: $*=P<0.05$ vs. pre-injection locomotion; $\dagger=P<0.05$ vs. Saline 1 . 

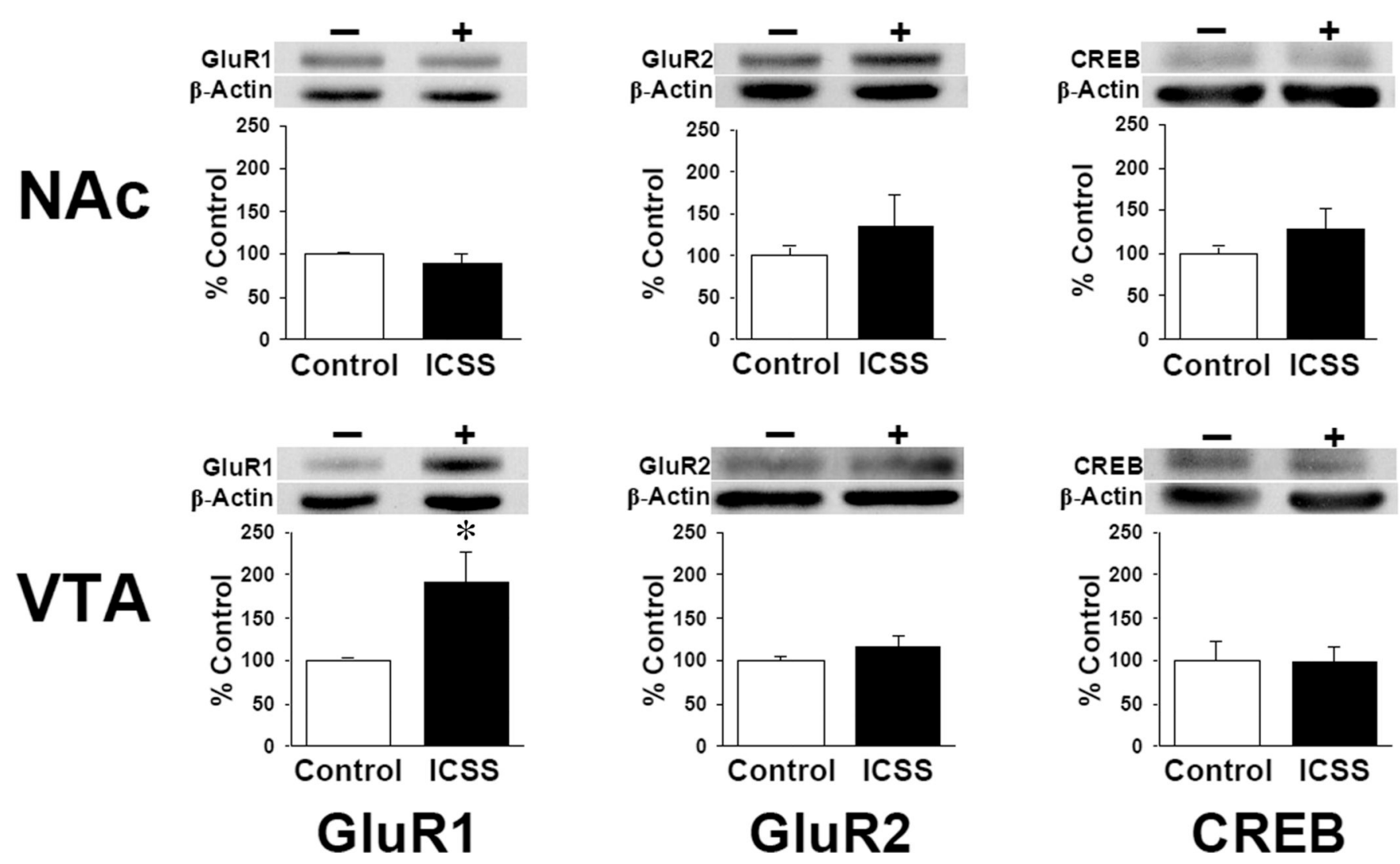

Figure 4.

ICSS increases total GluR1 in the VTA. Levels of AMPA receptor subunit proteins (GluR1; GluR2) and the CRE binding protein (CREB) in homogenates of tissue punches taken from the ventral tegmental area (VTA) and nucleus accumbens (NAc) on experimental day 7 (Figure 1; see Figure 2 for punch locations) are expressed as mean percentage change in ICSS mice compared to non-ICSS control mice \pm SEM. Western blots are shown from representative samples. - / White bars $=$ control $($ Group C; $n=6) ;+$ / black bars $=$ ICSS (Groups $\mathrm{A}$ and $\mathrm{B} ; n=10$ ); mice are the same from which behavioral data are shown in Figure $3 . *=P<0.05$ vs. controls. 


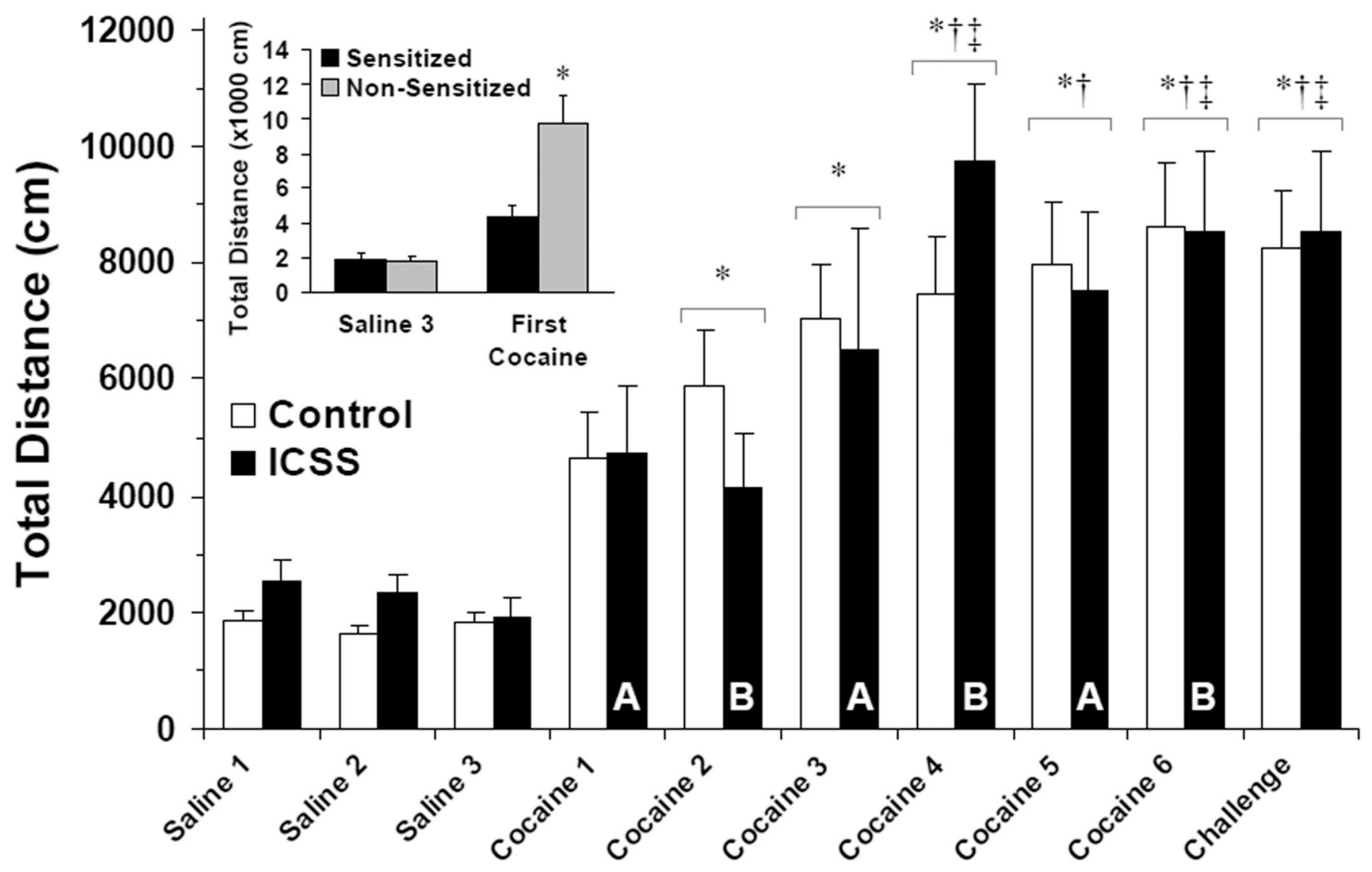

Figure 5.

ICSS does not alter locomotor sensitization to cocaine. Total locomotion over 30 minutes after injection of saline or cocaine $(15 \mathrm{mg} / \mathrm{kg}$ i.p. $)$ in sensitized mice at each time point is plotted as the mean distance traveled (in $\mathrm{cm}) \pm$ SEM. White bars $=$ Surgical and novelty control mice (Groups C and D, respectively; $n=20$ ); black bars $=$ ICSS mice (Groups A and $\mathrm{B} ; n=17$ ). Letters indicate ICSS group tested on that day (see Figure 1). No differences were seen between sensitized ICSS and sensitized control mice (see Results). Tukey's: * = $P<0.05$ vs. Saline $1-3 ; \dagger=P<0.05$ vs. Cocaine $1 ; \ddagger=P<0.05$ vs. Cocaine 2 . Inset: Total locomotion over 30 minutes on Saline 3 and the first presentation of cocaine in the locomotor apparatus (Cocaine 1 in Group A, Cocaine 2 in Group B, see Figure 1) to all ICSS mice. Sensitized ICSS mice, $n=17$; Non-Sensitized ICSS mice, $n=7$. * $=P<0.05$ vs. Sensitized. 

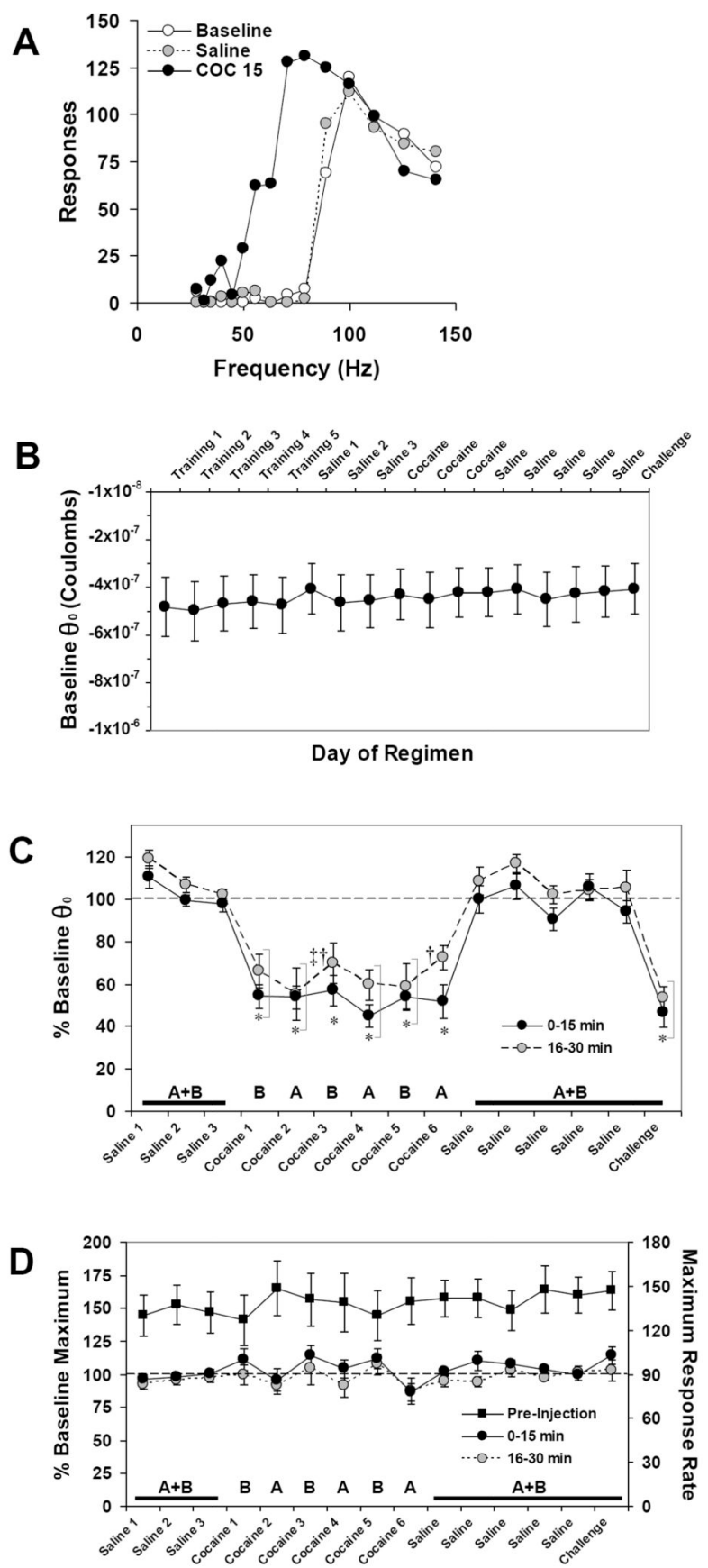

Figure 6.

BSR potentiation does not sensitize to cocaine. (A) Representative ICSS rate-frequency curves before (white circles) and after injection of saline (gray circles, dashed) or cocaine $\left(15 \mathrm{mg} / \mathrm{kg}\right.$ i.p., black circles). In this mouse, baseline pre-injection BSR threshold $\left(\theta_{0}\right)$ was $77.9 \mathrm{~Hz}$, was unchanged $(78.8 \mathrm{~Hz})$ after saline injection; and was lowered by cocaine $(15$ $\mathrm{mg} / \mathrm{kg}$ i.p.) to $41.0 \mathrm{~Hz}$, or $53 \%$ of baseline $\theta_{0}$. (B) Baseline pre-injection BSR threshold values expressed as mean charge delivery (in Coulombs) at $\theta_{0} \pm$ SEM over the course of the experiment. (C) Changes from baseline $\theta_{0}$ after each injection expressed as the mean percentage of pre-injection $\theta_{0} \pm$ SEM. Because the maximum effect of cocaine on BSR occurs within the first 15 minutes after injection, only the first two post-injection epochs (30 
minutes total) are shown for clarity; see Results for details. (D) Pre-injection maximum number of responses (right ordinate) and changes in maximum operant response rates after each injection expressed as the mean percentage of pre-injection maximum response rates (left ordinate) \pm SEM. In $(\mathbf{C}$ and $\mathbf{D})$ letters indicate group tested on that day (see Figure 1). Black squares $=$ pre-injection maximum operant response rate/minute $(n=17)$. Tukey's: $*=$ $P<0.05$ vs. all saline days; $\ddagger=P<0.05$ vs. Saline $1-3 ; \dagger=P<0.05$ vs. first day of cocaine withdrawal (Saline). 

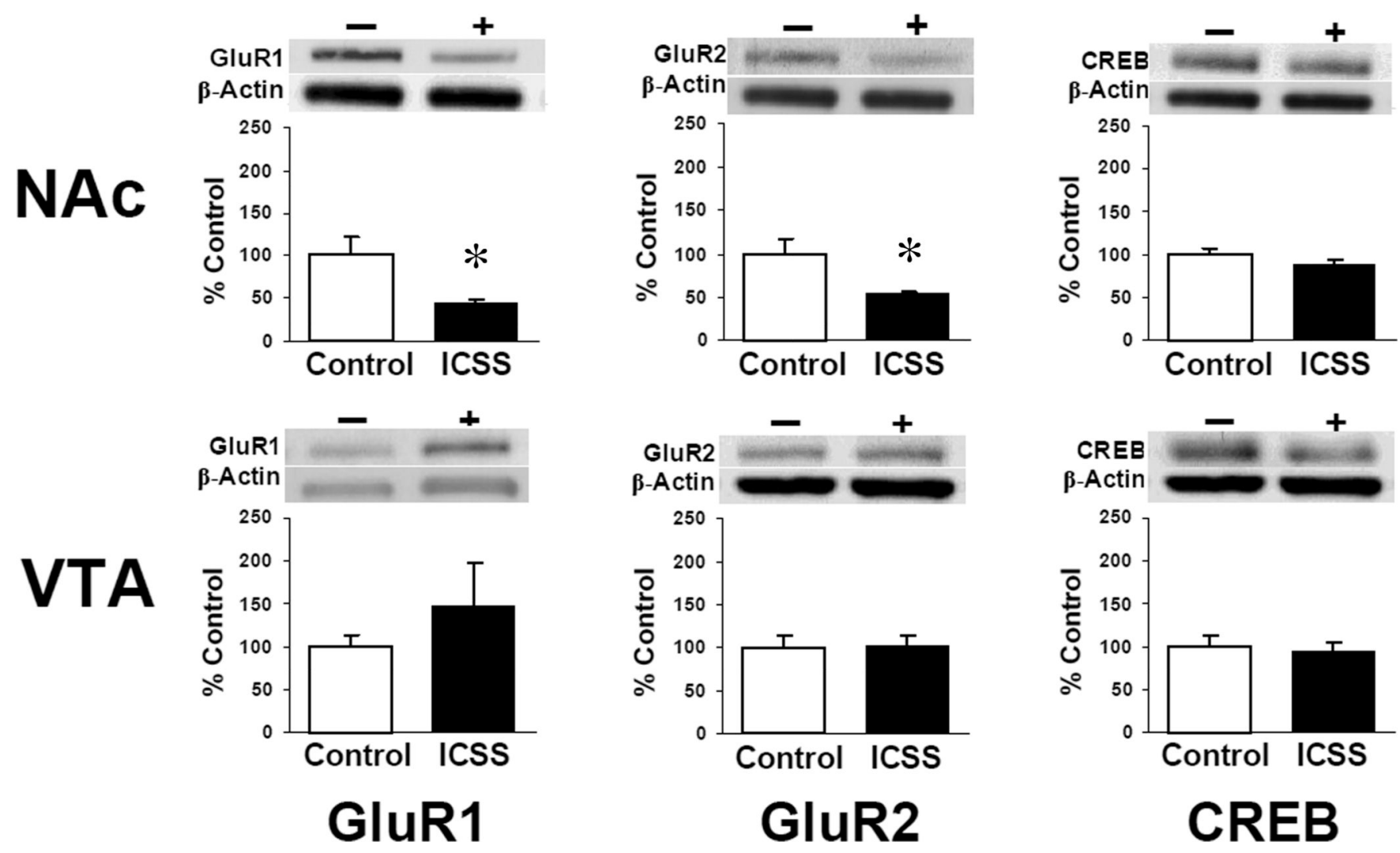

Figure 7.

Levels of AMPA receptor subunit proteins (GluR1; GluR2) and the CRE binding protein (CREB) from homogenates of tissue punches taken from the ventral tegmental area (VTA) and nucleus accumbens (NAc) 24 hours after completion of cocaine sensitization experiments (see Figure 2 for punch locations). Western blots are shown from representative samples; data are expressed as mean percentage change in ICSS mice compared to nonICSS control mice \pm SEM. $-/$ White bars $=$ control (Groups C and D; $n=11) ;+/$ black bars $=$ ICSS (Groups A and B; $n=8) ; *=P<0.05$ vs. controls. 


\section{TABLE 1}

Comparison of GluR1, GluR2 and CREB levels in non-ICSS control mice before (Group C; $n=6)$ and after (Groups $\mathrm{C}$ and $\mathrm{D} ; n=11$ ) repeated intermittent cocaine administration, withdrawal and cocaine challenge (see Figure 1).

\begin{tabular}{lccc} 
& \multicolumn{3}{c}{ Ventral Tegmental Area (VTA) } \\
& GluR1 & GluR2 & CREB \\
\hline Before Cocaine (Day 7) & $1.01 \pm 0.20$ & $0.70 \pm 0.18$ & $2.74 \pm 0.64$ \\
After Cocaine (Day 34) & $1.69 \pm 0.40$ & $1.84 \pm 0.33^{*}$ & $1.43 \pm 0.13$ \\
\hline & \multicolumn{4}{c}{ Nucleus Accumbens (NAc) } \\
& GluR1 & GluR2 & CREB \\
\hline Before Cocaine (Day 7) & $1.89 \pm 0.46$ & $2.09 \pm 0.42$ & $1.21 \pm 0.05$ \\
After Cocaine (Day 34) & $0.93 \pm 0.23^{*}$ & $0.49 \pm 0.08^{*}$ & $0.55 \pm 0.12^{*}$ \\
\hline
\end{tabular}

All values are expressed as mean ratio of optical density of bands to $\beta$-Actin in the same sample \pm SEM.

${ }^{*}$-test for unmatched samples (2-tailed) $P \leq 0.05$ vs. Day 7 .

See Results for details. 